\title{
Assessment of the lower urinary tract symptoms after robotic-assisted radical prostatectomy: the behavior of voiding, storage and post micturition symptoms.
}

\section{Avaliação dos sintomas do trato urinário inferior após prostatectomia radical robótica-assistida: o comportamento dos sintomas de esvaziamento, armazenamento e pós-miccionais}

Jose Arnaldo Shiomi da-Cruz, TCBC-SP1,2 (D); Sabrina Thalita dos Reis Faria ${ }^{1}$; Leandro Freitas Faria ${ }^{1}$; José Pontes-Junior ${ }^{1,2}$; Miguel Srougl, TCBC-SP'; William Carlos Nahas ${ }^{1}$; Carlo Carmargo Passerotti ${ }^{1,2}$.

\section{A B S T R A C T}

\begin{abstract}
Introduction: despite being infrequent, urinary incontinence has a huge impact on the quality of life of patients undergoing radical prostatectomy, even with the robotic-assisted technique. Objective: to assess the evolution of urinary symptoms from preoperative to 12 months after robotic-assisted radical prostatectomy. Methods: data was collected from 998 patients who underwent robotic-assisted radical prostatectomy. Demographic data, preoperative and postoperative information on patients were documented. The ICIQ and IPSS questionnaires were also applied preoperatively and after 1, 3, 6 and 12 months after the operation. Results: Out of 998 patients, 257 correctly completed all questionnaires. The mean age of the patients was $60 \pm 0.74$ years. We found that the total IPSS increased initially and at 6 months after the operation, it was already lower than the initial preoperative value (7.76 at 6 months vs. 9.90 preoperative, $p$ $<0.001$ ), being that questions regarding voiding symptoms were the first to improve followed by the questions regarding post micturition and storage symptoms. As for the ICIQ variables, there was an increase with radical prostatectomy and none of them returned to the preoperative level $(p<0.001)$. Conclusions: robotic assisted radical prostatectomy causes, at first, a worsening of urinary symptoms in the lower tract with subsequent recovery. Recovery begins with voiding symptoms, followed by post micturition and storage symptoms. The symptoms assessed by the IPSS evolve to better parameters even than those of the preoperative period, while the symptoms of incontinence assessed by the ICIQ do not reach the preoperative levels in the studied interval.
\end{abstract}

Keywords: Prostatic Neoplasms. Prostatectomy. Urinary Incontinence. Lower Urinary Tract Symptoms.

\section{INTRODUCTION}

P rostate cancer $(P C)$ is the most common noncutaneous tumor in men and the second leading cause of death from cancer in Brazil. It is responsible for $13.4 \%$ of deaths from cancer in males. For the year 2020, 65,840 new cases are estimated ${ }^{1}$.

Robotic-assisted radical prostatectomy has shown promise in the treatment of localized prostate cancer, with excellent functional and oncological results ${ }^{2-4}$. Urinary incontinence after radical prostatectomy represents a major problem for patients when it occurs. The primary cause is incompetence and weakness of the urethral sphincter, known as stress urinary incontinence. Urgent urinary incontinence may be present in some cases, which may be due to bladder dysfunction, leading to pure or mixed urgent incontinence, and exacerbating coexisting stress urinary incontinence ${ }^{5}$.

In view of the difficulty in measuring symptoms objectively, several instruments have been created to assess various facets of the patient with prostate cancer, including urinary symptoms, erectile function and urinary dysfunction. Among these instruments, two

1 - Faculdade de Medicina da Universidade de São Paulo, Disciplina de Urologia - São Paulo - SP - Brasil

2 - Hospital Alemão Oswaldo Cruz, Centro Especializado em Cirurgia Robótica - São Paulo - SP - Brasil 
main ones can be mentioned: the International Prostatic Symptom Score (IPSS) and the International Consultation Incontinence Questionnaire $(\mathrm{ICIQ})^{6}$.

The IPSS was created in 1992 by the American Urological Society under the name of American Urological Association Symptom Score (AUA-7) and was intended to assess urinary symptoms related to benign hyperplasia. The structure was composed of seven questions related to urinary symptoms ${ }^{7}$. Subsequently, an eighth question was included by the International Consultancy on benign prostatic hyperplasia sponsored by the World Health Organization (WHO), which renamed the questionnaire as the International Prostate Symptom Score and defined it as the instrument of choice for the evaluation of lower tract urinary symptoms ${ }^{8}$.

The International Consultation on Incontinence Questionnaire is a tool developed in 1998 at the first International Consultation on Incontinence (ICI), an interdisciplinary, multinational meeting held in Monaco and sponsored by WHO. After several meetings with numerous authorities to evaluate studies on quality of life, continence disorders, and designing of tools, a universally applicable questionnaire was developed, brief and with results collected directly from patients on urinary incontinence. Thus, it was possible to standardize the research tools on the subject, in order to facilitate the collection and sharing of data between groups ${ }^{9}$.

The objective of this study is to evaluate lower urinary tract symptoms in patients undergoing roboticassisted radical prostatectomy from the preoperative period up to the first twelve months after the procedure.

\section{METHODS}

This is a study of prospectively collected data, assessing prostatic and urinary symptoms of 998 patients undergoing treatment for prostate cancer through robotic-assisted radical prostatectomy, between March 2010 and May 2018, at the Hospital Alemão Oswaldo Cruz (HAOC). Data collection comprised records on demographics (age, body mass index), preoperative PSA(Prostate Specific Antigen) level, prostate volume (measured by nuclear magnetic resonance when available or by ultrasound), intraoperative data (total operative time, aspirated blood) and anatomical- pathological data (volume of the surgical specimen, tumor volume, tumor extension, surgical margins, seminal vesicle invasion, tumor staging, ISUP (Internation Society of Urological Pathology Score), and number of lymph nodes removed). The patients also answered a questionnaire with the Portuguese-validated versions of the IPSS and the ICIQ in the preoperative period and repeated the questionnaire after one, three, six and 12 months after radical prostatectomy. This project was approved by the ethics committees of the participating institutions (Approval 1318/09). Patients diagnosed with localized prostate cancer who arrived at the participating institutions coming from the Unified Health System were invited to participate in the study, as were patients in the private practice of one of the authors (CP). After reading, understanding and signing the Informed Consent Form, patients who agreed to participate in the study before performing the surgical procedure filled out two questionnaires.

We included candidates for radical prostatectomy, with clinically localized or locally advanced tumors, without metastases or oligometastics and who accepted to participate in the study. We excluded patients who had undergone extensive previous abdominal surgery or previous radiotherapy, or those for whom we could not record all the variables to be analyzed or who did not complete all questionnaires. Continence was defined as the use of up to 1 security pad per day.

We described preoperative quantitative variables according to groups using descriptive measures. We compared them with the postoperative moments with the ANOVA for variables with normal distribution and with the Kruskal-Wallis test for variables with nonnormal distribution. We performed all statistical analyzes using the Stata 11 statistical software (StataCorp, Texas, USA), with a $5 \%$ significance level.

\section{RESULTS}

We evaluated 998 patients, of whom 257 completed the preoperative questionnaire and had all the information to be studied. The average age was 60 \pm 0.74 years, the mean body mass index, $26.88 \pm 0,47$ $\mathrm{kg} / \mathrm{m}^{2}$, the average preoperative PSA $6.15 \pm 0.36 \mathrm{ng} /$ 
$\mathrm{ml}$, the mean prostate volume, $38.6 \pm 2.0 \mathrm{~g}$, the mean operative time, $149 \pm 4.4$ minutes, the average aspirated blood was $282 \pm 24 \mathrm{~mL}$, the prostate volume in the surgical specimen was on average $40.7 \pm 4.3 \mathrm{~g}$, the mean tumor volume, $6.45 \pm 0.64 \mathrm{~g}$, and an average of $4.4 \pm 0.8$ lymph nodes were removed. Thirtyone patients $(12 \%)$ had unilateral tumor, while two hundred and twenty-six (88\%) had bilateral lesions; $2.9 \%$ of patients had a positive proximal margin; $5.9 \%$ had a positive distal margin; $3.8 \%$ had seminal vesicle invasion; $29.6 \%$ had a positive circumferential margin; $29.6 \%$ had an extraprostatic tumor extension. As for the ISUP score, 62 (24\%) of the patients were ISUP 1, 152 (59\%) ISUP 2, 38 (15\%) ISUP 3, no patient was ISUP 4 , and there were five (2\%) ISUP 5 patients. As for pathological staging, 203 (79\%) patients were pT2, 46 (13\%) were pT3a, and $8(3 \%)$ were pT3b.

The evaluation of the IPSS performed through the validated questionnaire was obtained from 257 patients in the preoperative period, 220 (85\%) patients in the first postoperative month, 191 (74\%) in the third month, 155 ( $60 \%$ ) in the sixth postoperative month, and 139 (54\%) 12 months after the operation. Preoperative continence was $98 \%$, decreasing to $43 \%$ one month after radical prostatectomy, increasing to $61 \%$ three months after the procedure, then to $76 \%$ at six months, and finally reaching $89.9 \%$ urinary continence 12 months after radical prostatectomy

We evaluated the behavior of the total IPSS and of each question individually from the preoperative period up to 12 months. The preoperative IPSS value was $9.80 \pm 8.1$. In the first month after radical prostatectomy it increased to $14.50 \pm 7.7$, decreased to $10.62 \pm 6.82$ in the third month after the procedure, continuing to decrease six months after the procedure, to $7.76 \pm 6.45$, that is, lower than the preoperative value, and decreasing again after 12 months, to $6.30 \pm$ 6.54. This variation was statistically significant, with $p$ $<0.001$. Table 1 shows the behavior of each question of the IPSS individually.

The results of the questions 1,2,3, 5 and the ICIQ score are depicted in Table 2. Question 4 in divided in eight subitens assessing in which occasions the patient leaks urine, as discriminated in Table 3.

Table 1. IPSS evolution.

\begin{tabular}{|c|c|c|c|c|c|c|}
\hline & $\begin{array}{c}\text { Pre-operative } \\
\text { (mean } \\
\text { standard } \\
\text { deviation) }\end{array}$ & $\begin{array}{l}1 \text { month } \\
\text { (mean } \pm \\
\text { standard } \\
\text { deviation) }\end{array}$ & $\begin{array}{l}3 \text { months } \\
\text { (mean } \pm \\
\text { standard } \\
\text { deviation) }\end{array}$ & $\begin{array}{l}6 \text { months } \\
\text { (mean } \pm \\
\text { standard } \\
\text { deviation) }\end{array}$ & $\begin{array}{l}12 \text { months } \\
\text { (mean } \pm \\
\text { standard } \\
\text { deviation) }\end{array}$ & $\mathrm{p}$ \\
\hline $\begin{array}{l}\text { Question } 1 \\
\text { (Incomplete } \\
\text { emptying) }\end{array}$ & $1.28 \pm 1.70$ & $1.89 \pm 1.87$ & $1.33 \pm 1.58$ & $0.96 \pm 1.44$ & $0.81 \pm 1.41$ & $<0.001$ \\
\hline $\begin{array}{l}\text { Question } 2 \\
\text { (Frequency) }\end{array}$ & $1.87 \pm 1.83$ & $3.11 \pm 1.71$ & $2.36 \pm 1.69$ & $1.81 \pm 1.68$ & $1.40 \pm 1.64$ & $<0.001$ \\
\hline $\begin{array}{l}\text { Question } 3 \\
\text { (Intermittency) }\end{array}$ & $1.23 \pm 1.63$ & $1.53 \pm 1.78$ & $1.11 \pm 1.45$ & $0.67 \pm 1.24$ & $0.69 \pm 1.36$ & $<0.001$ \\
\hline $\begin{array}{l}\text { Question } 4 \\
\text { (Urgency) }\end{array}$ & $0.97 \pm 1.50$ & $2.55 \pm 1.93$ & $1.64 \pm 1.71$ & $1.07 \pm 1.61$ & $0.73 \pm 1.18$ & $<0.001$ \\
\hline $\begin{array}{l}\text { Question } 5 \\
\text { (Weak stream) }\end{array}$ & $1.61 \pm 1.83$ & $1.88 \pm 1.88$ & $1.26 \pm 1.62$ & $0.83 \pm 1.34$ & $0.63 \pm 1.19$ & $<0.001$ \\
\hline $\begin{array}{l}\text { Question } 6 \\
\text { (Straining) }\end{array}$ & $0.84 \pm 1.45$ & $0.75 \pm 1.34$ & $0.48 \pm 1.03$ & $0.34 \pm 0.86$ & $0.27 \pm 0.82$ & $<0.001$ \\
\hline $\begin{array}{l}\text { Question } 7 \\
\text { (Nocturia) }\end{array}$ & $2.00 \pm 1.55$ & $2.87 \pm 1.42$ & $2.41 \pm 1.48$ & $2.05 \pm 1.45$ & $1.75 \pm 1.54$ & $<0.001$ \\
\hline $\begin{array}{l}\text { Question } 8 \\
\text { (Quality of life) }\end{array}$ & $2.68 \pm 1.97$ & $3.82 \pm 1.84$ & $3.24 \pm 1.83$ & $2.96 \pm 1.98$ & $2.05 \pm 1.99$ & $<0.001$ \\
\hline
\end{tabular}


Table 2. Evolution of questions $1,2,3$ and 5 of the ICIQ.

\begin{tabular}{|c|c|c|c|c|c|c|}
\hline & $\begin{array}{c}\text { Pre-operative } \\
\text { (mean } \pm \text { standard } \\
\text { deviation) }\end{array}$ & $\begin{array}{l}1 \text { month } \\
\text { (mean } \pm \\
\text { standard } \\
\text { deviation) }\end{array}$ & $\begin{array}{l}3 \text { months } \\
\text { (mean } \pm \\
\text { standard } \\
\text { deviation) }\end{array}$ & $\begin{array}{l}6 \text { months } \\
\text { (mean } \pm \\
\text { standard } \\
\text { deviation) }\end{array}$ & $\begin{array}{l}12 \text { months } \\
\text { (meant } \\
\text { standard } \\
\text { deviation) }\end{array}$ & $p$ \\
\hline $\begin{array}{l}\text { Question } 1 \text { (how often } \\
\text { the patient leaks urine) }\end{array}$ & $0.52 \pm 1.13$ & $3.64 \pm 1.24$ & $2.77 \pm 1.59$ & $1.94 \pm 1.63$ & $1.37 \pm 1.60$ & $<0.001$ \\
\hline $\begin{array}{l}\text { Question } 2 \text { (how much } \\
\text { urine the patient leaks ) }\end{array}$ & $0.47 \pm 0.95$ & $2.98 \pm 1.48$ & $2.49 \pm 1.46$ & $1.76 \pm 1.40$ & $1.33 \pm 1.33$ & $<0.001$ \\
\hline $\begin{array}{l}\text { Question } 3 \text { (how much } \\
\text { leaking urine inter-fere } \\
\text { in everyday life) }\end{array}$ & $1.16 \pm 2.77$ & $5.13 \pm 3.50$ & $3.77 \pm 3.44$ & $2.51 \pm 3.26$ & $1.94 \pm 3.12$ & $<0.001$ \\
\hline $\begin{array}{l}\text { Sum Questions } 1+2+3 \\
\text { (ICIQ - score) }\end{array}$ & $2.19 \pm 3.91$ & $11.77 \pm 5.24$ & $9.03 \pm 5.68$ & $6.22 \pm 5.40$ & $4.68 \pm 5.31$ & $<0.001$ \\
\hline $\begin{array}{l}\text { Question } 5 \text { (number of } \\
\text { pads) }\end{array}$ & $0.15 \pm 0.46$ & $2.16 \pm 1.67$ & $1.53 \pm 1.51$ & $0.91 \pm 1.18$ & $0.54 \pm 0.96$ & $<0.001$ \\
\hline
\end{tabular}

Table 3. ICIQ question 4 answers.

\begin{tabular}{lcccccc}
\hline Time (months) & & Preoperative & 1 & 3 & 6 & 12 \\
\hline $\mathrm{n}$ & & 257 & 220 & 191 & 155 & 139 \\
Never & No & $43(17 \%)$ & $205(93 \%)$ & $166(87 \%)$ & $112(73 \%)$ & $79(57 \%)$ \\
$\mathrm{p}<0.001$ (chi-square) & Yes & $214(83 \%)$ & $15(7 \%)$ & $25(13 \%)$ & $43(27 \%)$ & $30(43 \%)$ \\
Before get to the toilet & No & $243(95 \%)$ & $152(59 \%)$ & $157(82 \%)$ & $122(78 \%)$ & $126(90 \%)$ \\
$\mathrm{p}<0.001$ (chi-square) & Yes & $14(5 \%)$ & $68(41 \%)$ & $34(18 \%)$ & $33(22 \%)$ & $13(10 \%)$ \\
cough or sneeze & No & $251(97 \%)$ & $104(47 \%)$ & $105(55 \%)$ & $104(67 \%)$ & $103(74 \%)$ \\
$p<0.001$ (chi-square) & Yes & $6(3 \%)$ & $116(53 \%)$ & $86(45 \%)$ & $51(33 \%)$ & $36(26 \%)$ \\
Sleeping & No & $257(100 \%)$ & $189(85 \%)$ & $178(93 \%)$ & $141(91 \%)$ & $129(93 \%)$ \\
$p<0.001$ (chi-square) & Yes & $0(0 \%)$ & $31(15 \%)$ & $13(7 \%)$ & $14(9 \%)$ & $10(7 \%)$ \\
Exercise & No & $251(97 \%)$ & $132(60 \%)$ & $112(58 \%)$ & $111(71 \%)$ & $112(80 \%)$ \\
$p<0.001$ (chi-square) & Yes & $6(3 \%)$ & $88(40 \%)$ & $79(42 \%)$ & $44(29 \%)$ & $27(20 \%)$ \\
Finished urinating and dressed & No & $240(93 \%)$ & $161(73 \%)$ & $154(80 \%)$ & $126(81 \%)$ & $122(87 \%)$ \\
$p<0.001$ (chi-square) & Yes & $17(7 \%)$ & $59(27 \%)$ & $37(20 \%)$ & $29(19 \%)$ & $17(13 \%)$ \\
No obvious reason & No & $255(99 \%)$ & $153(69 \%)$ & $140(73 \%)$ & $122(78 \%)$ & $117(84 \%)$ \\
$p<0.001$ (chi-square) & Yes & $2(1 \%)$ & $67(31 \%)$ & $51(27 \%)$ & $33(22 \%)$ & $22(16 \%)$ \\
All the time & No & $257(100 \%)$ & $198(90 \%)$ & $182(95 \%)$ & $153(98 \%)$ & $137(98 \%)$ \\
$p<0.001$ (chi-square) & Yes & $0(0 \%)$ & $22(10 \%)$ & $9(5 \%)$ & $2(2 \%)$ & $2(2 \%)$ \\
\hline
\end{tabular}

\section{DISCUSSION}

In the present study, we found that the IPSS rose initially, probably due to surgical stress and the continence recovery process and, six months after the operation, it was already lower than the initial preoperative value 
(7.76 at the sixth months vs. 9.90 preoperatively). Unlike all previously published studies, we analyzed each IPSS question individually.

It is interesting to note that of the first seven IPSS questions, number 3 (intermittency), number 5 (weak stream), and number 6 (straining) deal with emptying symptoms, while questions 2 (frequency), 4 (urgency), and 7 (nocturia) deal with storage symptoms. Question 1 (incomplete emptying) deals with post-voiding symptoms. We observed that question 6 was the first whose score decreased to levels lower than the preoperative value one month after prostatectomy. The scores of questions 3 and 5 became inferior to the preoperative values after three months of prostatectomy, while the scores of questions 1 and 2 decreased to levels lower than the preoperative values after six months, and the remaining questions took 12 months to be less than the preoperative state. In other words, emptying symptoms were clearly the first to improve, while storage and post-voiding symptoms took longer to show clinical improvement. This is intuitive, since the mechanical obstruction of the prostate has been removed. However, this is the first study to document this finding through IPSS or the American Urological Association Symptom Score AUASS (which is nothing more than the IPSS without the eighth question).

The interest in studying the impact of complete prostate removal on lower urinary tract symptoms is not new. The first work to study this phenomenon dates back to 1999, by Schwartz and Lepor. In this study, 104 men with prostate cancer were evaluated before retropubic radical prostatectomy and 12 months after the operation, regarding urinary tract symptoms and satisfaction with the operation. In patients with mild urinary symptoms, there was no significant change in symptoms 12 months after the operation. In contrast, for patients with moderate to severe symptoms, radical prostatectomy resulted in a significant improvement in urinary symptoms, as well as in the treatment of malignancy, in such a way that $98 \%$ of the operated patients were satisfied with the procedure ${ }^{10}$.

In 2014, Prabhu et al. published a study of 1,788 patients followed from the preoperative period to 10 years after radical retropubic prostatectomy. Patients had an initial worsening of lower urinary tract symptoms, which improved between three and 24 months after surgery. Patients with lower urinary tract symptoms prior to the operation (IPSS > 7) had immediate symptoms remission after surgery, this improvement persisting for 10 years after the procedure. Men without clinically significant symptoms (IPSS up to 7) showed a notable increase (3.09 to 4.94, p <0.001) in IPSS over the years, but without clinical relevance. The percentage of men with clinically significant lower urinary tract symptoms declined from baseline in 10 years after RP $(p=0.02)$. Thus, radical prostatectomy is the treatment for prostate cancer that improves and prevents the development of lower urinary tract symptoms (LUTS) in the long-term follow-up. This durable, previously unrecognized benefit argues in favor of the prostate as the main contributor to male LUTS ${ }^{11}$.

Gordon et al. studied 666 men undergoing robotic radical prostatectomy. Patients with mild LUTS experienced short-term increases in IPSS, but most returned to baseline and stabilized after five years. Preoperative benefits were found in men with moderate and severe LUTS, in whom $63 \%$ had significant improvements in quality of life (QOL) and 68\% had decreased AUASS similar to IPSS - for mild LUTS, persisting with low values years after the robotic-assisted procedure. This study suggests that certain patients with preoperative urinary symptoms and discomfort may experience improvements in LUTS and associated QOL after robotic-assisted radical prostatectomy ${ }^{12}$.

In our sample, we found that all ICIQ variables were elevated with radical prostatectomy and none returned to the preoperative stage.

Machioka et al. evaluated 258 cases with the ICIQ-SF and the questions about the daily use of diapers and diaper weight in 24 hours, for objective assessment. The total ICIQ-SF score before and one, three, six and 12 months after PR was 0, 10, 7.5 and 4, respectively. The incontinence patterns differed when comparing the ICIQSF results before and after prostatectomy. There was a significant correlation between the total ICIQ-SF score, 24hour diaper weight, and daily diaper usage. However, the distribution of points on each scatterplot varied widely. When comparing the results before prostatectomy and 12 months after, there was complete recovery for 35\% of the patients from the total ICIQ-SF score, $67 \%$ of the daily use of diapers and $64 \%$ of the 24 -hour weight test. Only $29 \%$ of patients had scores decreased to preoperative levels ${ }^{13}$.

Fujimura et al. evaluated 607 patients 
undergoing robotic radical prostatectomy using the ICIQ and the Core Lower Urinary Tract Symptom Score (CLSS), from the preoperative period to 24 months postoperatively. After the procedure, stress urinary incontinence (SUI) was reported (32\%) as the main complaint, with the greatest impact on daily life assessed by the CLSS questionnaire, followed by urgent urinary incontinence (UUI; 27\%). The continence recovery rates varied between different types of urinary incontinence, such as after urinating, when dressed, sleeping, when physically active or exercising, when coughing or sneezing, before going to the bathroom and for no obvious reason ${ }^{14}$.

Limani et al. studied 272 patients who underwent robotic-assisted radical prostatectomy. They completed the ICIQ and other quality of life questionnaires preoperatively and one, three, 12 and 24 months after the procedure. All scores (ICIQ, UI discomfort and urinary symptoms) were significantly modified and worsened when compared with preoperative values; in particular, the median ICIQ went from 1 to $10 ; 20 \%$ of patients were very uncomfortable with urinary symptoms (compared with $2 \%$ preoperatively). There was a progressive improvement in all scores in late assessments (12 to 24 months), with significantly improved quality of life ${ }^{15}$.

In the present work, we had the inherent limitations of observational studies, even though we collected the data prospectively. Despite the large number of patients, few had all variables available and many did not complete the questionnaires satisfactorily during the study period. In addition, the sample is limited to the number of patients available and not to the sample calculation that should be done routinely in any study.

There is still great heterogeneity in the definition of incontinence itself. There are authors who advocate that any use of diaper is considered incontinence, while there are more permissive ones that accept up to two diapers a day. In this study, we accepted the limit of one diaper a day, because there is a known large proportion of patients who use it to feel safer when practicing daily activities, but many go through the day with the diaper absolutely dry.

From the present study, it is possible to verify that not only the total scores (the sum of questions 1 , 2 and 3 of the ICIQ and the sum of questions 1 to 7 of the IPSS), seems to have value in the study of urinary continence after radical prostatectomy. Further studies should pay more attention to these tools to understand the evolution of lower urinary tract symptoms after radical prostatectomy and, thus, be able to treat urinary incontinence in the best manner.

\section{CONCLUSIONS}

Robotic-assisted radical prostatectomy initially worsened lower tract urinary symptoms, with subsequent recovery. Improvement begun with symptoms of emptying, followed by post-voiding and storage ones. The symptoms evaluated by the IPSS eventually reached better parameters, even considering the preoperative values, while the symptoms of urinary loss assessed by the ICIQ did not reach the preoperative levels in the studied interval.

\title{
R E S U M O
}

\begin{abstract}
Introdução: apesar de infrequente, a incontinência urinária gera imenso impacto na qualidade de vida dos pacientes submetidos a prostatectomia radical, mesmo com a técnica robótica-assistida. Objetivo: avaliar a evolução dos sintomas urinários desde o préoperatório até 12 meses após a prostatectomia radical robótica-assistida. Métodos: foram coletados os dados de 998 pacientes submetidos à prostatectomia radical robótica-assistida. Foram documentados dados demográficos, informações pré-operatórias e pós-operatórias dos pacientes. Também foram aplicados os questionários ICIQ e IPSS no pré-operatório e após 1, 3, 6 e 12 meses de pós-operatório. Resultados: de 998 pacientes, 257 preencheram corretamente todos os questionários. A idade média dos pacientes foi de $60 \pm 0,74$ anos. Verificou-se que o IPSS total subia inicialmente e aos 6 meses após a operação, este já se tornava inferior ao valor inicial pré-operatório $(7,76$ aos 6 meses vs. 9,90 pré-operatório, $p<0.001)$, sendo que as questões referentes a sintomas de esvaziamento foram as primeiras a melhorar e posteriormente as questões referentes a sintomas pós-miccionais e de armazenamento. Quanto às variáveis do $\mathrm{ICIQ}$, houve elevação com a prostatectomia radical e nenhuma delas retornou ao patamar pré-operatório $(p<0,001)$. Conclusões: a prostatectomia radical robótica assistida causa num primeiro momento uma piora nos sintomas urinários do trato inferior com uma recuperação subsequente. A recuperação se inicia pelos sintomas de esvaziamento, seguido dos sintomas pós-miccionais e de armazenamento. Os sintomas avaliados pelo IPSS acabam evoluindo a parâmetros melhores inclusive que os do pré-operatório, enquanto os sintomas de perda urinária avaliados pelo ICIQ não atingem os níveis pré-operatórios no intervalo estudado.
\end{abstract}

Palavras chave: Neoplasias da Próstata. Prostatectomia. Incontinência Urinária. Sintomas do Trato Urinário Inferior. 


\section{REFERENCES}

1. Instituto Nacional de Câncer José Alencar Gomes da Silva [Internet]. 2020 [acesso em 2020 abr 10]. Disponível em: www.inca.gov.br.

2. Berryhill R Jr., Jhaveri J, Yadav R, Leung R, Rao S, El-Hakim $A$, et al. Robotic prostatectomy: a review of outcomes compared with laparoscopic and open approaches. Urology. 2008;72(1):15-23.

3. Dasgupta P, Patil K, Anderson C, Kirby R. Transition from open to robotic-assisted radical prostatectomy. BJU Int. 2008;101(6):667-8.

4. Hung SC, Yang CK, Cheng CL, Ou YC. Long-term Oncologic Outcomes of Robotic-assisted Radical Prostatectomy by a Single Surgeon. Anticancer Res. 2017;37(8):4157-64.

5. Heesakkers J, Farag F, Bauer RM, Sandhu J, De Ridder D, Stenzl A. Pathophysiology and contributing factors in postprostatectomy incontinence: A review. Eur Urol. 2017;71(6):936-44.

6. Juszczak K, Ostrowski A, Bryczkowski M, Adamczyk $P$, Drewa T. A hypothesis for the mechanism of urine incontinence in patients after radical prostatectomy due to urinary bladder hypertrophy. Adv Clin Exp Med. 2019;28(3):347-51.

7. Lujan Galan M, Paez Borda A, Martin Oses E, Llanes Gonzalez L, Berenguer Sanchez A. [The validity of the IPSS questionnaire in a sample of 262 patients with benign prostatic hyperplasia]. Arch Esp Urol. 1997;50(8):847-853. Spanish.

8. Cockett AT, Aso Y, Denis L, Khoury S, Barry M, Carlton $C E$, et al. World Health Organization Consensus Committee recommendations concerning the diagnosis of $\mathrm{BPH}$. Prog Urol. 1991;1(6):957-72.

Received in: 06/05/2020

Accepted for publication: 06/07/2020

Conflict of interest: no.

Funding source: none.
9. Abrams P, Avery K, Gardener N, Donovan J, Board $I A$. The International Consultation on Incontinence Modular Questionnaire: www.iciq.net. J Urol. 2006;175(3 Pt 1):1063-1066; discussion 1066.

10. Schwartz EJ, Lepor $H$. Radical retropubic prostatectomy reduces symptom scores and improves quality of life in men with moderate and severe lower urinary tract symptoms. J Urol. 1999;161(4):1185-8.

11. Prabhu V, Taksler GB, Sivarajan G, Laze J, Makarov DV, Lepor H. Radical prostatectomy improves and prevents age dependent progression of lower urinary tract symptoms. J Urol. 2014;191(2):412-7.

12. Gordon A, Skarecky D, Osann K, Eichel L, Dhaliwal $H$, Morales B, et al. Quantification of Long-term Stability and Specific Relief of Lower Urinary Tract Symptoms (LUTS) After Robot-assisted Radical Prostatectomy. Urology. 2016;93:97-103.

13. Machioka K, Kadono $Y$, Naito R, Nakashima K, lijima $M$, Kawaguchi $S$, et al. Evaluating urinary incontinence before and after radical prostatectomy using the international consultation on incontinence questionnaire-short form. Neurourol Urodyn. 2019;38(2):726-33.

14. Fujimura $T$, Igawa $Y$, Aizawa N, Niimi A, Yamada $Y$, Sugihara $T$, et al. Longitudinal change of comprehensive lower urinary tract symptoms and various types of urinary incontinence during robotassisted radical prostatectomy. Neurourol Urodyn. 2019;38(4):1067-75.

15. Limani K, Albisinni S, Aoun F, Le Dinh D, I Biaou, E Hawaux, et al. Qualité de vie après prostatectomie robotique: impact des indices de masse corporelle et âge sur l'incontinence urinaire. Prog Urol. 2017;27(4):244-52.

\section{Mailing address:}

Carlo Carmargo Passerotti

E-mail: carlopasserotti@hotmail.com 